\title{
INSECTICIDAL ACTIVITY OF DIENAMIDES ON CABBAGE CATERPILLAR AND BENEFICIAL INSECTS
}

\author{
Mayara Cristina Lopes, ${ }^{\mathrm{a}}$ Elson Santiago Alvarenga ${ }^{\mathrm{c}, *}$ Alex Ramos Aguiar, ${ }^{\mathrm{c}}$ Izailda Barbosa dos Santos, ${ }^{\mathrm{b}}$ Gerson Adriano \\ Silva, ${ }^{d}$ Lucas de Paula Arcanjo ${ }^{\mathrm{b}}$ and Marcelo Coutinho Picanço ${ }^{\mathrm{b}}$ \\ a'Departamento de Fitotecnia, Universidade Federal de Viçosa, Viçosa - MG, Brasil \\ bepartamento de Entomologia, Universidade Federal de Viçosa, Viçosa - MG, Brasil \\ 'Departamento de Química, Universidade Federal de Viçosa, Viçosa - MG, Brasil \\ ${ }^{\mathrm{d}}$ Centro de Ciências e Tecnologias Agropecuárias, Universidade Estadual Norte Fluminense, Campos dos Goytacazes - RJ, Brasil
}

Recebido em 15/08/2017; aceito em 21/12/2017; publicado na web em 01/02/2018

\begin{abstract}
The demand for new insecticides is increasing due to the appearance of insect populations that are resistant to currently used products. New insecticides should be efficient in controlling pests and present low toxicity to non-target organisms. Ascia monuste (Lepidoptera: Pieridae) is a destructive pest of cole vegetables, and the fire ant Solenopsis saevissima (Hymenoptera: Formicidae) is an important predator of these caterpillars in brassica crops. Tetragonisca angustula (Hymenoptera: Apidae) is very important in pollinating many plants and providing honey. Therefore, this study evaluated the toxicity of synthetic amides to A. monuste and its selectivity in favor of $S$. saevissima and $T$. angustula. The amides ( $2 E, 4 E)-N$-propylhexa-2,4-dienamide (3) and (2E,4E)- $N$-butylhexa-2,4-dienamide (4) caused high ( 96 and $93 \%$, respectively) and fast ( $48 \mathrm{~h}$ ) mortality of A. monuste. The amides $\mathbf{3}$ and $\mathbf{4}$ were not harmful to the predator (mortality of $5.7 \%$ for amide $\mathbf{3}$ and $\mathbf{7 . 1 4 \%}$ for amide $\mathbf{4}$ ) and were slightly harmful to the pollinator (mortality of $38.57 \%$ for amide 3 and $28.12 \%$ for amide $\mathbf{4}$ ). The amides $\mathbf{3}$ and $\mathbf{4}$ are promising, as insecticides, due to the high and rapid mortality of A. monuste with low and moderate toxicity to $S$. saevissima and $T$. angustula, respectively.
\end{abstract}

Keywords: Solenopsis saevissima; stingless bee; fire ant; selectivity; insecticide.

\section{INTRODUCTION}

Insect pests are one of the major problems faced by man both in urban and rural environments. Insecticide is the main tool used to control these organisms. ${ }^{1}$ However, due to successive applications of insecticides, the selection of insect populations resistant to these products occurs..$^{2-4}$ Thus, it is important to find new molecules with insecticidal activity. These insecticides need to be efficient in controlling the pests and present low toxicity to humans and a low impact on beneficial organisms, such as natural enemies and pollinators. ${ }^{5,6}$

One option for the synthesis of new pesticides having suitable characteristics is the use of natural molecules as a model. As an example of these natural molecules we have pyrethrum, nicotine, ryanodine and amides, extracted from Chrysanthemum cinerariifolium, Nicotiana sp., Ryania speciosa, and Piper nigrum, respectively. ${ }^{5-8}$

Among the major groups of agricultural pests are the butterflies, which include Ascia monuste (Godart 1819) (Lepidoptera: Pieridae). This pest is present in South America, Central America and North America and attacks plants of the Brassicaceae family such as cabbage, broccoli, cauliflower, tall cabbage, brussels sprout, kohlrabi, Chinese cabbage, mustard, canola, cress, radish and arugula. ${ }^{9}$ The larvae of A. monuste can cause losses of up to $100 \%$ in crop production due to plant defoliation. ${ }^{10}$

The fire ant Solenopsis saevissima (Smith 1855) (Hymenoptera: Formicidae) is a social insect that lives in colonies; these insects are organized into castes (workers, soldiers and royal caste) and are usually found in soil. ${ }^{11}$ Fire ants are generalist predators of arthropods in the natural environment and in agroecosystems; their prey is mainly an immature stage (eggs, larvae and pupae) of Coleoptera, Diptera, Hemiptera, Lepidoptera and Orthoptera. ${ }^{12,13}$

Another important group of social insects associated with ecosystems are bees (Hymenoptera: Apidae). Bees produce honey and are important pollinators of plants. Pollination by bees is extremely important in agricultural crops, and they account for $90 \%$ of the reproductive success of flowering plants. ${ }^{14}$ The stingless bee Tetragonisca angustula (Latreille 1825) (Hymenoptera: Apidae) is an important species in the Neotropical region..$^{15}$ T. angustula is a small bee (4-5 mm), with a yellow/brown color. ${ }^{16}$ This bee is geographically distributed throughout Latin America, in colonies of from 2-5 thousand individuals who are found in voids of walls and trees, and in the soil. ${ }^{17}$

During foraging, the natural enemies and pollinators may be exposed to pesticides used for pest control. This exposure can cause death or reduce lifespan, fertility, fecundity, sex ratio, and time of development and cause alterations in behavior related to food seeking and mating. ${ }^{18,19}$ An example of the negative effect of pesticides on pollinators has been observed in the population of honey bees, known as colony collapse disorder (CCD). CCD is an abrupt disappearance of a honey bee colony. ${ }^{20,21}$ One hypothesis for the disappearance of bee populations is the use of some insecticide groups such as neonicotinoids. ${ }^{22}$

Given the importance of A. monuste as a pest of brassica and the role of natural enemies and pollinators in the natural environment and in agroecosystems, this study aimed to determine the toxicity of synthetic amides (whose insecticidal activity is unknown) to $A$. monuste and its selectivity in favor of the predator S. saevissima and the pollinator T. angustula. In this context, we have prepared nine amides from readily available potassium sorbate, which possess a diene conjugated to the carboxylate group (Figure 1). This configuration makes the amides prepared structurally connected to piperine, which is a natural insecticide from black pepper.

\section{EXPERIMENTAL}

\section{General}

The progress of the reactions was monitored by visualization of 
<smiles>C/C=C/C=C/C(=O)OC(C)C(C)Cl</smiles><smiles>C/C=C/C=C/C(=O)NCCNC(=O)NCC</smiles>

Figure 1. Syntheses of the amides (1-9) from potassium sorbate. Amines employed in the syntheses, reaction yields and melting points of the amides are described in Table 1

thin layer chromatography plates (TLC) in an ultraviolet irradiation chamber with a 254-nm lamp. ${ }^{19}$ All compounds were purified using column chromatography on silica gel (60-230 mesh). Melting points were obtained using a MQAPF-301 melting point apparatus and were not corrected. Infrared (IR) spectra were acquired using a PERKIN ELMER SPECTRUM 1000 spectrometer. The samples were analyzed as $\mathrm{KBr}$ pellets. Nuclear magnetic resonance (NMR) spectra were recorded using a Varian Mercury $300 \mathrm{MHz}$ spectrometer using $\mathrm{CDCl}_{3}$ as solvent. The ${ }^{1} \mathrm{H}$ NMR chemical shifts were reported using the residual signal of $\mathrm{CHCl}_{3}(\delta=7.27 \mathrm{ppm})$ as a reference. ${ }^{13} \mathrm{C} \mathrm{NMR}$ chemical shifts were recorded using the $\mathrm{CDCl}_{3} \operatorname{signal}(\delta=77.0 \mathrm{ppm})$ as a reference. The mass spectra were obtained using SHIMADZU GC-MS-QP5050A and GC-MS-QP2010 Ultra equipment after $70 \mathrm{eV}$ electron impact ionization (EI).

\section{Synthesis of amides}

Nine dienamides were synthesized from potassium sorbate. Potassium sorbate $(10 \mathrm{~g}, 67.5 \mathrm{mmol})$ was suspended in $\mathrm{CH}_{2} \mathrm{Cl}_{2}$ $(100 \mathrm{~mL})$ and acidified with hydrochloric acid $1 \mathrm{~mol} \mathrm{~L}^{-1}(100 \mathrm{~mL})$ in a separating funnel. The mixture was shaken for $10 \mathrm{~min}$, and the organic phase was separated. The aqueous phase was extracted with $\mathrm{CH}_{2} \mathrm{Cl}_{2}(50 \mathrm{~mL})$, and the combined organic phase was dried with magnesium sulfate. The hydrated magnesium sulfate was removed by filtration and the filtrate was concentrated under vacuum to afford the ( $2 E, 4 E)$-hexa-2,4-dienoic acid. Oxalyl chloride $(1.0 \mathrm{~mL}, 11.5 \mathrm{mmol})$ was added to a solution of ( $2 E, 4 E)$-hexa-2,4-dienoic acid ( $0.5 \mathrm{~g}, 4.46$ mmol) in anhydrous $\mathrm{CH}_{2} \mathrm{Cl}_{2}(20 \mathrm{~mL})$. Subsequently, the solvent and excess oxalyl chloride were removed under reduced pressure in a rotary evaporator to afford a green oil. The green oil was dissolved in dry $\mathrm{CH}_{2} \mathrm{Cl}_{2}(20 \mathrm{~mL})$ and transferred to a round-bottomed flask. The corresponding amine $(11.5 \mathrm{mmol})$ was added to the ice-cooled reaction mixture (Table 1) and was stirred under a nitrogen atmosphere for two hours. The solvent was removed on a rotary evaporator under reduced pressure, and the residue was chromatographed on a silica gel column using a mixture of hexane and ethyl acetate as eluent to afford amides (1-9), which are shown in Table 1.

\section{Insects}

In the bioassays, we use larvae of the second instar of $A$. monuste, adults from the predatory ant $S$. saevissima and adult bees T. angustula. Adults of S. saevissima and T. angustula were collected from nests on the campus of the Universidade Federal de Viçosa (UFV), Viçosa, Minas Gerais State, Brazil (20484'5”S, 4256'15”'W, $600 \mathrm{~m}$ altitude and tropical weather)

A. monuste larvae were reared in a greenhouse on the UFV campus. We initiated this rearing of $A$. monuste by larvae collected from commercial cabbage in Viçosa and maintained them in a greenhouse. The population was reared in a laboratory at a photophase of $12 \mathrm{~h}$, a temperature of $25 \pm 0.5{ }^{\circ} \mathrm{C}$ and a relative air humidity of $75 \pm 5 \%$. The larvae were fed with leaves from cabbage plants and cultivated under greenhouse conditions without any insecticide application. The adults of A. monuste were fed with a honey solution (20\%). The oviposition of butterflies was held in cabbage plants. The larvae were fed with cabbage leaves and pupation occurred in the greenhouse.

To establish the doses used in the bioassays we evaluated the body mass of 20 individuals of each species in an analytical balance (Gehaka, AG 200, accuracy $0.1 \mathrm{mg}$ ). The average body weights of the insects were $1.40 \mathrm{mg}$ for the A. monuste second instar larvae,

Table 1. Amines employed in the syntheses, reaction yields and melting points of the amides (1-9).

\begin{tabular}{|c|c|c|c|c|}
\hline Amine used in the synthesis & Melting point $/{ }^{\circ} \mathrm{C}$ & Reaction yield & Product & Amide \\
\hline $\mathrm{CH}_{3} \mathrm{NH}_{2}$ & $80.6-81.3$ & $74 \%$ & $\begin{array}{c}(2 E, 4 E)-N \text {-methylhexa-2,4-dienamide } \\
\mathrm{SW}=21.28\end{array}$ & 1 \\
\hline $\mathrm{CH}_{3} \mathrm{CH}_{2} \mathrm{NH}_{2}$ & $68.5-69.6$ & $69 \%$ & $\begin{array}{c}(2 E, 4 E) \text { - } N \text {-ethylhexa-2,4-dienamide } \\
\mathrm{SW}=10.86\end{array}$ & 2 \\
\hline $\mathrm{CH}_{3}\left[\mathrm{CH}_{2}\right]_{2} \mathrm{NH}_{2}$ & $82.3-84.1$ & $86 \%$ & $\begin{array}{c}(2 E, 4 E)-N \text {-propylhexa-2,4-dienamide } \\
\mathrm{SW}=4.14\end{array}$ & 3 \\
\hline $\mathrm{CH}_{3}\left[\mathrm{CH}_{2}\right]_{3} \mathrm{NH}_{2}$ & $59.3-60.1$ & $68 \%$ & $\begin{array}{c}(2 E, 4 E) \text { - } N \text {-butylhexa-2,4-dienamide } \\
\mathrm{SW}=2.34\end{array}$ & 4 \\
\hline$\left(\mathrm{CH}_{3}\right)_{2} \mathrm{CHNH}_{2}$ & $108.1-109.7$ & $57 \%$ & $\begin{array}{c}(2 E, 4 E)-N \text {-isopropylhexa-2,4-dienamide } \\
\mathrm{SW}=4.29\end{array}$ & 5 \\
\hline$\left(\mathrm{CH}_{3}\right)_{2} \mathrm{CHCH}_{2} \mathrm{NH}_{2}$ & $87.9-88.7$ & $73 \%$ & $\begin{array}{l}(2 E, 4 E)-N \text {-isobutylhexa-2,4-dienamide } \\
\mathrm{SW}=2.34\end{array}$ & 6 \\
\hline \multirow[t]{3}{*}{$\mathrm{CH}_{3}\left[\mathrm{CH}_{2}\right]_{9} \mathrm{NH}_{2}$} & $81.9-82.7$ & $77 \%$ & $\begin{array}{c}(2 E, 4 E)-N \text {-decylhexa-2,4-dienamide } \\
\mathrm{SW}=0.02\end{array}$ & 7 \\
\hline & $99.5-100.1$ & $41 \%$ & $\begin{array}{c}(2 E, 4 E)-N \text {-(2-(pyrrolidin-1-yl)ethyl)hexa-2,4-dienamide } \\
\mathrm{SW}=2.5\end{array}$ & 8 \\
\hline & $153.3-154.7$ & $52 \%$ & $\begin{array}{c}(2 E, 4 E)-N \text {-(1-benzylpiperidin-4-yl)hexa-2,4-dienamide } \\
\mathrm{SW}=0.16\end{array}$ & 9 \\
\hline
\end{tabular}

$\mathrm{SW}=$ solubility in water at $\mathrm{pH} 7\left(\mathrm{~g} 100 \mathrm{~mL}^{-1}\right)$. All amides were obtained as a white solid except amides $\mathbf{4}$ and $\mathbf{8}$, which were isolated as a yellow solid. 
$0.77 \mathrm{mg}$ for the adults of $S$. saevissima and $4.0 \mathrm{mg}$ for the adults of T. angustula.

\section{Toxicity of substances to larvae of $A$. monuste}

We conducted the bioassays in a room at a temperature of $27 \pm 2{ }^{\circ} \mathrm{C}$, a relative humidity of $75 \pm 5 \%$ and a photophase of $12 \mathrm{~h}$. We performed three bioassays to assess the toxicity of the amides to $A$. monuste. In the first bioassay, we selected the amides with insecticidal activity against $A$. monuste. In the second experiment, we estimated dose-mortality curves for the amides selected in the first bioassay. In the third bioassay, we estimated time-mortality curves for the amides selected in the first bioassay. In the three bioassays, the experimental design was completely randomized. Each replicate consisted of a Petri dish ( $9 \mathrm{~cm}$ in diameter $\mathrm{x} 2 \mathrm{~cm}$ in height) containing ten second instar A. monuste larvae. Cabbage leaf disk was used to feed the larvae.

The substances were dissolved in acetone (Vetec P.A. 99.5\%), and topical application was completed with the aid of a $10-\mu \mathrm{L}$ microsyringe (Hamilton model 701N). Piperine was used as a standard of efficiency, and acetone was used as the treatment control. Each insect was treated with $0.5 \mu \mathrm{L}$ of the previously mentioned solution.

\section{Selection of the amides with insecticidal activity against the insect pest $A$. monuste}

The dose used was $30 \mathrm{mg}$ of substance per gram of insect body mass. In this bioassay six replicates were used for each treatment. The treatments consisted of nine synthetic amides, piperine (amide used as efficiency standard) and the control (pure acetone).

We evaluated the insect mortality $48 \mathrm{~h}$ after treatment application. The mortality included both dead individuals and those that were no longer moving. A. monuste mortality data were subjected to analysis of variance and treatment means were compared by Tukey test. We selected for the next bioassays amides that resulted in greater than $80 \%$ mortality to A. monuste as this is the criterion used in Brazil for an insecticide to be considered effective in controlling a pest. ${ }^{3,4}$ Pearson correlation analysis was performed between the mortality of A. monuste and the molecular weight and water solubility of the corresponding amides.

\section{Determination of dose-mortality curves of the amides with higher insecticidal activity against the insect pest $A$. monuste}

The experimental design, the repetitions and the methodology used were the same as the previous bioassay. The treatments consisted of different doses of the two amides selected in the previous bioassay and the control (acetone). We used six (2.5, 5.0, 12.5, 13.0, 17.5 and $30.0 \mathrm{mg}$ per $\mathrm{g}$ of insect) and seven doses $(0.15,0.75,1.25,2.0,5.0$, 15.0 and $30.0 \mathrm{mg}$ per $\mathrm{g}$ of insect) of amides 3 and 4, respectively. The insect mortality was evaluated $48 \mathrm{~h}$ after treatment application.

Mortality data were corrected according to the Abbott (1925) formula. ${ }^{23}$ The corrected mortalities were submitted to Probit analysis ${ }^{24}$ using the PROC PROBIT procedure of SAS. ${ }^{25}$ The curves were accepted when they presented a probability higher than 0.05 by $\chi^{2}$ test (Young and Young 1998). Using these curves, we estimated median lethal dose $\left(\mathrm{LD}_{50}\right)$ and lethal dose $90\left(\mathrm{LD}_{90}\right)$ for the amides 3 and 4 to A. monuste and the $95 \%$ confidence intervals of these features.

\section{Determination of survival curves for the most toxic amides to A. monuste}

The treatments were the $\mathrm{LD}_{90}$ of the selected amide (20.89 and $6.75 \mathrm{mg}$ of amides 3 and 4 per g of insect, respectively) and control (acetone). A total of 120 insects were used per treatment. The mortalities of insects were evaluated during the period from 0 to $48 \mathrm{~h}$ from the assembly of the bioassay.

Using the experimental data, the insect survival curves were estimated using the Kaplan-Meier product limit method. ${ }^{25}$ Using the survival curves, we estimated the median lethal time $\left(\mathrm{LT}_{50}\right)$ of the amides to A. monuste. The $\mathrm{LT}_{50}$ of the amides were considered different when their average was outside of the $95 \%$ confidence interval of another substance.

\section{Selectivity of the amides in favor of $S$. saevissima and $T$. angustula}

The treatments against $A$. monuste were the $\mathrm{LD}_{90}$ of the selected amides and the control (acetone). The insects used in this bioassay were second instar larvae of the insect pest $A$. monuste, adults of the predator S. saevissima and adults of the pollinator bee T. angustula. The experimental plots used for A. monuste were similar to those used in other bioassays. For the predator and the pollinator, each experimental plot consisted of a Petri dish $(9 \mathrm{~cm}$ in diameter $\mathrm{x} 2 \mathrm{~cm}$ in height) containing 10 adults. Prior to application of the treatments, adults of $T$. angustula were kept under refrigeration for one minute in order to anesthetize them to facilitate topical application. A piece of wet cotton ( $1 \mathrm{~cm}$ in diameter) and a plastic container $(1.5 \mathrm{~cm}$ in diameter $\mathrm{x} 1 \mathrm{~cm}$ in height) with food (85\% sugar and 15\% honey) to feed the insects were placed in the bottom of the Petri dish. Six replicates were used per treatment. The insect mortality was evaluated 48 hours after treatment. The mortalities of S. saevissima and $T$. angustula under each treatment were compared to the mortality of the insect pest $A$. monuste by t-test at $P<0.05$.

\section{RESULTS AND DISCUSSION}

\section{Toxicity of the substances to the insect pest $A$. monuste}

We detected significant differences in the mortality of $A$. monuste larvae caused by the treatments $(F=121.20$; $\mathrm{df}=55 ; P<0.001)$. The substances could be divided into three groups according to the mortality of A. monuste larvae (at a dose of $30 \mathrm{mg}$ of substance per $\mathrm{g}$ of insect). The first group contains piperine and amides 3 and 4 , which were the substances that caused the highest mortality (96 and $93 \%$ respectively) of A. monuste. The second group is composed of the amides 2, 5 and 9, which caused intermediate mortality (47 to 55\%) of $A$. monuste. In the third group are the amides $1,6,7$ and 8 , which were the substances that caused the lowest mortality of $A$. monuste; these mortalities were similar to the control (Figure 2). Therefore, amides 3 and 4 were selected for subsequent assays. We did not observe significant correlations between the mortalities caused by the substances (at a dose of $30 \mathrm{mg} \mathrm{g}^{-1}$ ) with their molecular weights $(\mathrm{r}=0.04, \mathrm{t}=0.11, P=0.457)$ and water solubility $(\mathrm{r}=-0.30 ; \mathrm{t}=0.89$; $P=0.206$ ) (Figura 2 e MS Information).

These results indicate that the variation in the chemical structures of amides was not related to its insecticidal activity as the nine amides studied have similar structures. In this context, substances with similar chemical structure may have different insecticidal activity. That is, two isomers can have different insecticidal activity, with one having low activity while the other having high activity. ${ }^{8,15,26}$ Generally, substances with lower molecular weight and less solubility in water tend to have higher insecticidal activity. This difference is due to greater penetration of these molecules into the insect's cuticle. ${ }^{27-29}$ However, this has not been noted here as the solubility and molecular weight of the amides were not related to their insecticidal activities. 


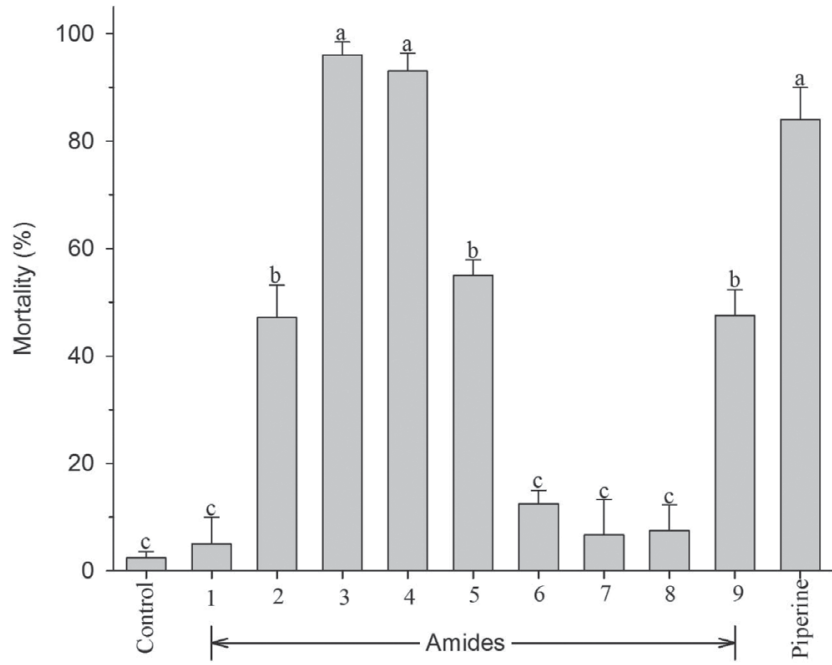

Figure 2. Mortality (mean \pm standard error) of second instar larvae of the insect pest Ascia monuste caused by the application of nine synthetic amides, piperine (dose $=30 \mathrm{mg}$ per $\mathrm{g}$ of insect) and control. The means of histograms followed by the same letter do not differ as estimated by the Tukey test at $P<0.05$

When A. monuste larvae were exposed to different doses of the substances, we observed that amide 4 showed a lower $\mathrm{LD}_{50}$ Therefore, amide 4 was more toxic to the pest than amide 3 . The slope of the curve dose-mortality for $A$. monuste for amide 3 was higher than the slope of this curve for amide 4 (Figure 3).

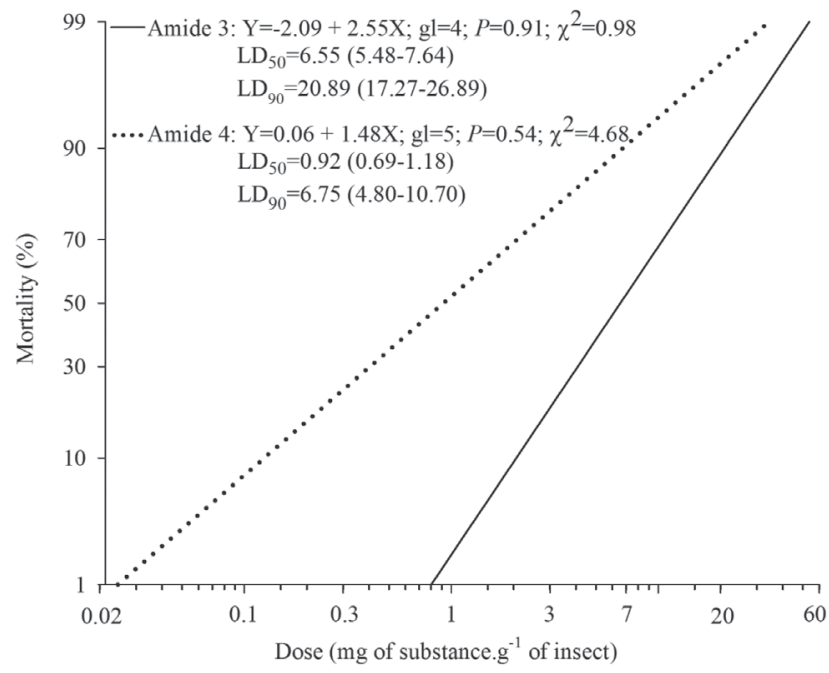

Figure 3. Dose mortality curves of amides 3 and 4 for second instar larvae of the insect pest Ascia monuste

These results indicate that the use of amide 4 possibly presents a lower cost for pest control than amide 3 as a smaller dose of the amide 4 is needed for effective pest control. An important fact in the use of pesticides is the control failures arising from the application of low doses of substances. In this context, substances that have dose-mortality curves with steeper slopes have a higher risk of control failures. Therefore, small variations in the dose result in large variations in the mortality of the pest. ${ }^{3,30}$ Thus, amide 4 presents a lower risk of control failure due to errors in application because it showed dose-mortality curve with a lower slope than that of amide 3.

There was no significant difference in the time mortality curves of $A$. monuste larvae treated with amides 3 and 4 (log-rank test, $\chi^{2}=$
$0.0261 ; \mathrm{df}=1 ; P=0.870)$. We found that 48 hours after application, $100 \%$ of $A$. monuste larvae were alive for the control (acetone), while $90 \%$ of the larvae were dead when treated with amides 3 and 4 (Figure 4). The median lethal time $\left(\mathrm{LT}_{50}\right)$ for $A$. monuste when treated with amides 3 [23 $\mathrm{h}$ and $30 \mathrm{~min}$. (21.0-32.0)] and 4 [26.0 h (24.0-29.0)] were similar.

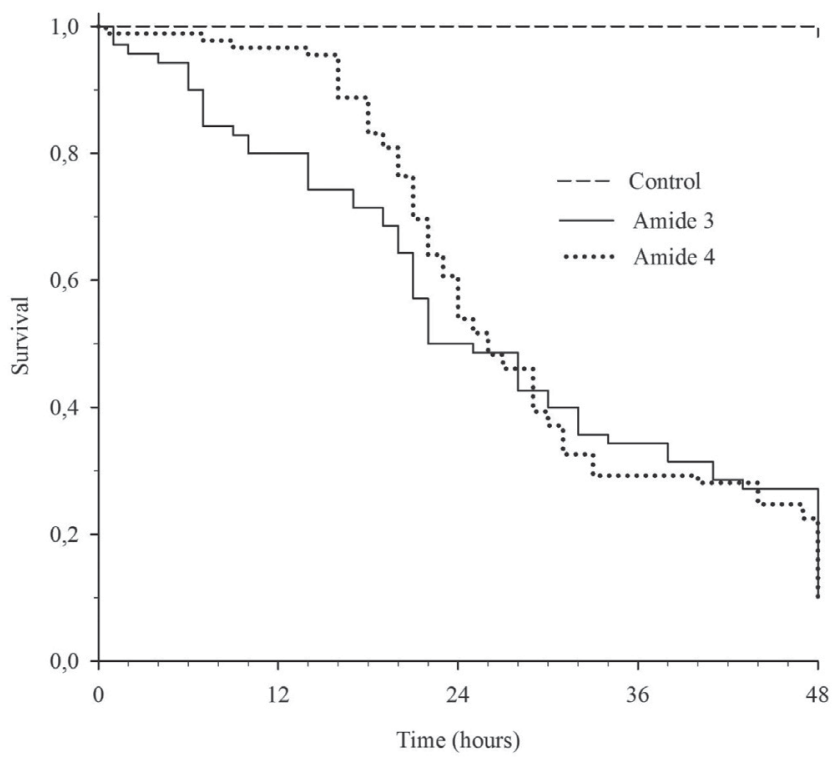

Figure 4. Survival curves for second instar larvae of the insect pest Ascia monuste for the control and when submitted to the $L D_{90}$ of amides 3 and 4

In situations of pest outbreaks, pests can cause economic damage to crops if not controlled quickly. ${ }^{31}$ In these situations, it is necessary to apply insecticides with fast-acting control, such as amides 3 and 4, to prevent damage to crops by pests. Therefore, these amides presented a fast-acting control of $A$. monuste (less than $48 \mathrm{~h}$ ).

\section{Selectivity of amides 3 and 4 to the predator $S$. saevissima and pollinator T. angustula}

The mortality of the A. monuste insect pest was higher than the predator S. saevissima, and the pollinator T. angustula for amides 3 and 4 . Amide 3 caused $96.0 \%$ mortality in the insect pest $A$. monuste, and 5.70 and $38.6 \%$ mortality for the predator S. saevissima and the pollinator T. angustula, respectively. Amide 4 caused $93.0 \%$ mortality in the insect pest $A$. monuste, 7.14 , and $28.1 \%$ mortality for the predator S. saevissima, and the pollinator T. angustula, respectively (Figure 5).

These results indicate that amides 3 and 4 were selective in favor of the predator S. saevissima as they caused low mortality $(<10 \%)$ of this natural enemy. In addition, the mortality induced by these two amides to the predator was lower than the mortality of A. monuste larvae. Selective insecticides in favor of natural enemies are the ideal products for use in integrated pest management programs because they are effective in controlling pests and preserve populations of natural enemies..$^{29,32}$

The fact that amides 3 and 4 were selective to the predator $S$. saevissima and showed low toxicity to the pollinator bee T. angustula is important for the preservation of these beneficial insects in agroecosystems as most commercial insecticides are non-selective to natural enemies and bees. In this context, Moreno et $_{\text {al }}{ }^{8}$ found that the commercial insecticide permethrin (pyrethroid) was 150 times more toxic to the predator $S$. saevissima and 2380 times more toxic to $T$. angustula in comparison to A. monuste. Additionally, Araújo et al. ${ }^{33}$ found that the commercial insecticides cartap (nereistoxin analogue), chlorfenapyr (pyrazole analogue), deltamethrin (pyrethroid), 
(A)

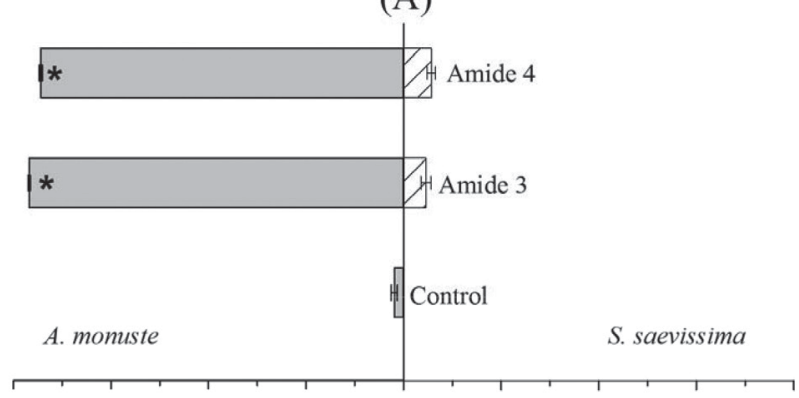

(B)

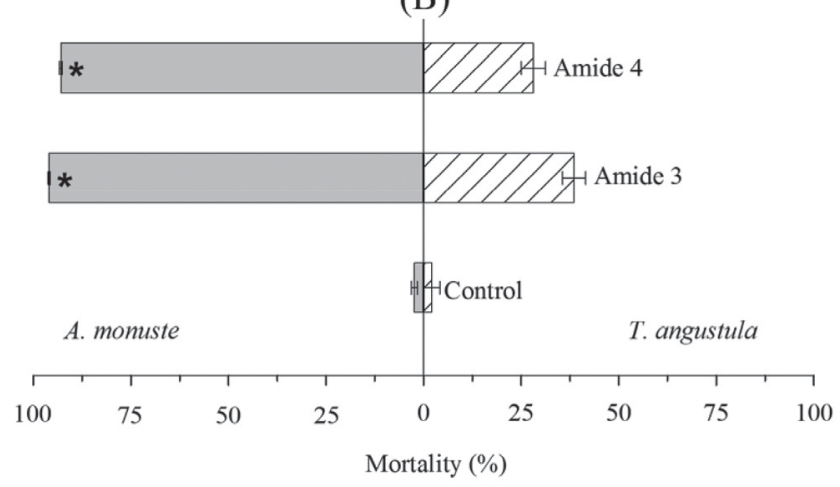

Figure 5. Comparison of the mortality (mean \pm standard error) caused by amides 3 and 4 to second instar larvae of the insect pest Ascia monuste and those observed for $(A)$ the predator Solenopsis saevissima and $(B)$ pollinator bee Tetragonisca angustula. The asterisk (* in the bars) indicates that the mortality of the pest under this treatment was higher than the predator or pollinator according to the t-test at $P<0.05$. The dose used was the $L D_{90}$ for the A. monuste larvae

malathion (organophosphate) and methomyl (carbamate) were nonselective to $S$. saevissima.

Before release, new insecticides must undergo a rigorous registration process that includes testing of acute and chronic toxicity to assess the risk to nontarget organisms, including natural enemies and honey bees. ${ }^{34}$ In this study, we demonstrated the low toxicity of two amides in two species of nontarget organisms; however, more studies will be conducted aiming to evaluate chronic effects of these compounds.

\section{CONCLUSIONS}

Amide 3 ((2E,4E)- $N$-propylhexa-2,4-dienamide) and amide 4 ((2E,4E)- $N$-butylhexa-2,4-dienamide) were toxic to larvae of $A$. monuste. The larvae of $A$. monuste are more sensitive to amide 3 than to amide 4 . Amide 4 is less toxic to pollinator T. angustula as compared to amide 3 .

\section{SUPPLEMENTARY MATERIAL}

Physical and spectrometric data of the amides are available at http://quimicanova.sbq.org.br as a free-access PDF file.

\section{ACKNOWLEDGMENTS}

We would like to thank the Chemical Network of Minas Gerais (Rede Mineira de Química - RQ-MG), National Council for Scientific and Technological Development (CNPq), Coordination for the Improvement of Higher Education Personnel (CAPES), and the Minas Gerais State Research Foundation (FAPEMIG) for the scholarships and resources provided.

\section{REFERENCES}

1. Matthews, G. A.; Crop Prot. 2008, 27, 834.

2. Whalon, M. E.; Mota-Sanchez, D.; Hollingworth, R. M.; Global pesticide resistance in arthropods, Cambridge: United Kingdom, 2008.

3. Silva, G. A.; Picanço, M. C.; Bacci, L.; Crespo, A. L. B.; Rosado, J. F.; Guedes, R. N. C. Pest Manag. Sci. 2011, 67, 913.

4. Gontijo, P. C.; Picanço, M. C.; Pereira, E. J. G.; Martins, J. C.; Chediak, M.; Guedes, R. N. C.; Ann. Appl. Biol. 2013, 162, 50.

5. Paula, V. F.; Barbosa, L. C. A.; Demuner, A. J.; Piló-Veloso, D.; Picanço, M. C.; Pest Manag. Sci. 2000, 56, 168.

6. Gradish, A. E.; Scott-Dupree, C. D.; Shipp, L.; Harris, C. R.; Ferguson, G.; Pest Manag. Sci. 2011, 67, 82.

7. Sattelle, D. B.; Cordova, D.; Cheek, T. R.; Invertebr. Neurosci. 2008, 8, 107.

8. Moreno, S. C.; Silvério, F. O.; Lopes, M. C.; Ramos, R. S.; Alvarenga, E. S.; Picanço, M. C.; J. Environ. Sci. Heal. B 2017, 52, 237.

9. Liu, T. X.; Ann. Entomol. Soc. Am. 2005, 98, 726.

10. Picanço, M. C.; Oliveira, I. R.; Rosado, J. F.; Silva, F. M.; Gontijo, P. C.; Silva, R. S.; Sociobiology 2010, 56, 1.

11. Ross, K. G.; Keller, L.; Annu. Rev. Ecol. Syst. 1995, 26, 631.

12. Knutson, A. E.; Campos, M.; Southwest Entomol. 2008, 33, 1.

13. Ramos, R. S.; Picanço, M. C.; Santana, Jr. P. A.; Silva, E. M.; Bacci, L.; Gonring, A. H. R.; Silva, G. A.; Sociobiology 2012, 59, 1389.

14. Shipp, J. L.; Whitfield, G. H.; Papadopoulos, A. P.; Sci. Hortic. 1994, $57,29$.

15. Moreno, S. C.; Picanço, M. C.; Silvério, F. O.; Alvarenga, E. S.; Carvalho, G. A.; Sociobiology 2009, 54, 893.

16. Van Zweden, J. S.; Grüter, C.; Jones, S. M.; Ratnieks, F. L. W.; Behav. Ecol. Sociobiol. 2011, 65, 1277.

17. Cortopassi-Laurino, M.; Nogueira-Neto, P.; Acta Amazonica 2003, 33, 643.

18. Stark, J. D.; Banks, J. E.; Annu. Rev. Entomol. 2003, 348, 505.

19. Desneux, N.; Decourtye, A.; Delpuech, J. M.; Annu. Rev. Entomol. 2007, 52,81 .

20. Bernal, J.; Garrido-Bailón, E.; Del-Nozal, M. J.; González-Porto, A. V.; Martín-Hernández, R.; Diego, J. C.; Jiménez, J. J.; Bernal, J. L.; Higes, M.; J. Econ. Entomol. 2010, 103, 1964.

21. Neuman, P.; Carreck, N. L.; J. Apicult. Res. 2010, 49, 1.

22. Goulson, D.; J. Appl. Ecol. 2013, 50, 977.

23. Abbott, W. S.; J. Econ. Entomol. 1925, 18, 265.

24. Finney, D. J.; Probit analysis, $3^{\text {th }}$ ed., Cambridge University Press: London, 1971.

25. SAS Institute; SAS User's Manual, Version 9.4; SAS Institute, Cary, USA, 2013.

26. Soderlund, D. M.; Clark, J. M.; Sheets, L. P.; Mullin, L. S.; Piccirillo, V. J.; Sargent, D.; Stevens, J. T.; Weiner, M. L.; Toxicology 2002, 171, 3.

27. Stock, D.; Holloway, P. J.; Pestic. Sci. 1993, 38, 165.

28. Bacci, L.; Picanco, M. C.; Rosado, J. F.; Silva, G. A.; Crespo, A. L. B.; Pereira, E. J. G.; Martins, J. C.; Appl. Entomol. Zool. 2009, 44, 103.

29. Pereira, R. R.; Picanço, M. C.; Santana Jr., P. A.; Moreira, S. S.; Guedes, R. N. C.; Corrêa, A.S.; Agr. Forest Entomol. 2014, 16, 293.

30. Siniard, D. J.; Wade, M. J.; Drury, D. W; BioRxiv (2016), doi: 10.1101/072520.

31. Barbosa, P.; Letourneau, D. K.; Agrawal, A. A.; Insect outbreaks revisited; Wiley: Chichester, 2012.

32. Onstad, D. W.; Insect resistance management: biology, economics and prediction, Academic Press: London, 2008.

33. Araújo, T. A.; Picanço, M. C.; Ferreira, D. O.; Campos, J. N. D.; Arcanjo, L. P.; Silva, G. A. Pest Manag. Sci. 2017, 73, 1.

34. Oldroyd, B. P.; PLoS Biol. 2007, 5, 1195. 